International Journal of Economics, Business and Accounting Research (IJEBAR)

Peer Reviewed - International Journal

Vol-4, Issue-3, 2020 (IJEBAR)

E-ISSN: 2614-1280 P-ISSN 2622-4771

http://jurnal.stie-aas.ac.id/index.php/IJEBAR

\title{
ANALYSIS OF DECISIONS TO PURCHASE VIRTUAL PRIVATE SERVER PRODUCT IN BALIKPAPAN
}

\author{
Lutfi Ahmad Gozali ${ }^{1}$, Suharno ${ }^{2}$, Gusti Noorlitaria Achmad ${ }^{3}$ \\ Faculty of Economic and Business, University of Mulawarman ${ }^{1,2,3}$ \\ E-mail:lutfi.gozali1@gmail.com, suharno@feb.unmul.ac.id, gusti.noolitaria.achmad@feb.unmul.ac.id
}

\begin{abstract}
The use of virtual private server technology is currently growing rapidly in companies to support companies developing applications that are implemented in the company. Lintasarta is a company that provides virtual private server products in Balikpapan which have 24-hour support and a team of internationally certified experts.Researchers are interested in analyzing the antecedents of purchasing decisions of virtual private server products in Balikpapan. The method used in this research is explanation by explaining the variables and objects examined through the collected data. Price, product quality, and technology acceptance models are the main focus discussed.This study took a sample of 30 companies in Balikpapan that use virtual private server products. The analysis technique used is Structural Equation Modeling (SEM) with partial Least Square (PLS) approach.The results showed that the price had a negative and not significant effect on purchase intentions. Product quality has a negative and not significant effect on purchase intention. Technology acceptance models have a positive and significant effect on purchase intentions. Price has a positive and not significant effect on purchasing decisions. Technology acceptance model has a negative and not significant effect on buying decisions. Intention to buy a positive and significant effect on product purchasing decisions.
\end{abstract}

Keywords: $\quad$ Price, Product Quality, Technology Acceptance Model, Purchase Intentions and Purchasing Decisions

\section{Introduction}

Technology is one of the technology products that is experiencing the most rapid development and progress among other technology products. Human nature as a social creature who wants to always interact to be the cause of the increasingly developing information technology in the modern era like today. Many benefits of information technology that can be felt by humans, one of which is to facilitate their daily activities in disseminating or receiving information.

Currently Information Technology (IT) is developing rapidly. This is marked by the rise of the application of IT in various fields of life. IT Company develops applications to simplify the work and reporting process. Applications require infrastructure including the Internet and server.

The server is a computer system that provides types of services such as applications for clients in a computer network. The development of server technology including Virtual Private Server (VPS). Next will be the short VPS. We will have a virtual server but we do not know where to place the server. VPS is managed by a data center provider so that users only rent VPS services according to the required server specifications. With a VPS rental system, users do not need to invest in the provision of servers and supporting infrastructure such as power supplies and air conditioners. VPS rental rates 
International Journal of Economics, Business and Accounting Research (IJEBAR)

Peer Reviewed - International Journal

Vol-4, Issue-3, 2020 (IJEBAR)

E-ISSN: 2614-1280 P-ISSN 2622-4771

http://jurnal.stie-aas.ac.id/index.php/IJEBAR

are very cheap because it uses a rental system. In addition to the affordable price, some data center providers offer price discounts to consumers if they use VPS with high specifications so that the price is cheaper.

Based on field observations made by the author that there is a concern of consumers to save the application in VPS because they do not know the location of the server and guarantee data security. Data center providers that provide VPS try to convince consumers to put their applications on VPS by providing guaranteed maintenance services, very fast response times to complaints about VPS problems, ease of use of VPS, very good quality of VPS. The price of VPS has also been affordable with the development of technology from server virtualization. VPS providers also increase more and more from year to year so that the price of VPS becomes more competitive and affordable.

The reason for this research is to analyze the variables that influence the purchase decision of virtual private servers that already have the intention to buy because there are some cases that have intention to buy but are not buying and some are suddenly not buying at PT Aplikanusa Lintasarta

\section{Foundation Of Theory And Development Of Hypotheses}

The relationship between price and purchase intention

Ehrman (2011) says that "The field of Promotion represents the 4th" P "of the Marketing Mix: Product, Price, Place and Promotion. The American Marching Association defines a company's total promotion mix as the specific blend of advertising, sales promotion, public relations, personal selling and those direct marketing tools that a company uses to persuasively communicate customer value and build customer relationships. This states that price promotions affect customer interest.

Rong-Da (2016) which states that price has a positive influence on customer motivation. Motivation influences behavior and stimulates customer purchasing responses (Justin et al., 2013).

The relationship between product quality and purchase intention

Mohd Rizaimy Shaharudin, et al. (2011) conducted a study on "The relationship between product quality and purchase intention: The case of Malaysia's national motorcycle / scooter manufacturer" with a sample of 300 respondents. This study uses SPSS version 17 with the results stating that product quality has a positive effect on product purchase intentions.

Richard Chinomona, et al. (2013) conducted a study on "The Concept of Product Quality on Perceived Value, Trust and Students' Attention to Purchase Electronic Gadgets" with a sample of 151 respondents in South Africa. This study uses Structural Equation Modeling (SEM) with a smart PLS approach with product quality results having a greater influence on student confidence in the product $(0.582)$ than the perceived product of $(0.474)$. The perceived product value influences trust $(0.217)$ but is insignificant to purchase intention (0.170). Nevertheless, trust also has a significant effect on purchase intention (0.494).

The relationship between technology acceptance models and purchase intentions

L. Richard Ye and Hao-hong Zhang (2014) conducted a study on "Sales Promotion and Purchasing Attention: Applying the Technology Acceptance Model in Consumer-to-Consumer Marketplaces" with a sample of 350 respondents using AMOS version 7.0 with the Perceived Usefulness effect having a significant positive effect on customer purchase intentions

Surpiko Hapsoro Darpito and Ida Wiendijarti (2015) conducted a study challenging "The Effect of Technology Acceptance Model on Purchasing Furniture and Handycrat for Smes Products Through Online Media in Yogyakarta" with a sample of 250 respondents using Structural Equation Modeling (SEM) with the results of variables in TAM affecting customer satisfaction, but does not affect the intention to buy in a store. But consumers spend their attention on social influences such as friends, family and the environment 
International Journal of Economics, Business and Accounting Research (IJEBAR)

Peer Reviewed - International Journal

Vol-4, Issue-3, 2020 (IJEBAR)

E-ISSN: 2614-1280 P-ISSN 2622-4771

http://jurnal.stie-aas.ac.id/index.php/IJEBAR

\section{The relationship between price and purchasing decisions}

Baruna Hadi Brata, et al. (2017) conducted research on "the Influence of Quality Products, Price, Promotion, and Location to Product Purchase Decision on Nitchi at PT. Jaya Swarasa Agung in Central Jakarta" with a sample of 115 respondents using SPSS with the results of product quality, price, promotion and location influences buying decisions even though it is partially not simultaneous.

Bing Xu and Jianhui Chen (2017) conducted a study on "Consumer Purchase Decision Making Process Based on the Traditional Clothing Shopping Form" with a sample of 501 respondents using SPSS version 17.0 with the result that price had a positive effect on purchasing decisions.

The relationship between product quality and purchasing decisions

Dr. Raed Ahmad Momani (2015) conducted a study on "The Impact of Brand Dimension on the Purchasing Decision Making of the Consumer Consumer Shopping Goods" with a number of 300 samples distributed in West Amman. This study uses SPSS with very weak quality results and historical traditions, and analysis shows that it is not significant.

According to Luthfia (2012) consumers in making purchasing decisions always consider matters related to the quality of the product to be purchased. Product quality can be interpreted as the ability of the product to carry out its functions which include durability, reliability or advancement, strength, ease of packaging and product repairs and other characteristics

The relationship between technology acceptance models and purchasing decisions

Choy Johnn Yee, et al. (2011) conducted a study of "Consumers' Perceived Quality, Perceived Value and Perceived Risk Towards Purchase Decision on Automobile" with a sample of 200 respondents with positive results on the combination of perceived quality, perceived value and perceived risk with purchasing decisions.

Andi Muh. Primabudi and Febriliyan Samopa (2017) conducted research on "Analysis of Factors Influencing Purchase Decisions in Online Stores. Case Study: Game Sales in Online Store "with a sample of 100 respondents using PLS-SEM with the result of risk perception having a significant positive effect on potential customers to buy Playstation 4 Blu-ray games at" XYZ "stores.

\section{The relationship between purchase intentions and purchasing decisions}

Yi Jin Lima, et al. (2016) conducted a study on "Factors Influencing Online Shopping Behavior: The Mediating Role of Purchase Intention" with a sample of 662 respondents conducted at the Perlis Malaysian University using SPSS and AMOS with the intention to buy positively influenced the online shopping behavior.

Azahari Jamaludin and Fais Ahmad (2013) conducted research on "Investigating the Relationship between Trust and Intention to Purchase Online" with a sample of 78 conducted at the Malaysian Institute of Information Technology (MIIT), University of Kuala Lumpur, Malaysia with the results of trust having a positive positive relationship. significant with buying intention towards online buying decisions.

\section{Research Methods}

The population in this study are consumers of PT Aplikanusa Lintasarta. This study uses 30 respondents. Respondents in this study are respondents who use PT Aplikanusa Lintasarta Balikpapan's virtual private server products. Based on this study because the population is not greater than 100 respondent companies, the authors take $100 \%$ of the population of companies in Balikpapan who buy VPS provider products in Balikpapan, as many as 30 respondent companies. The questionnaire was given to the decision makers in the company. Thus the use of the entire population without having to draw the research sample as an observation unit is called the saturated sample technique. 
International Journal of Economics, Business and Accounting Research (IJEBAR)

Peer Reviewed - International Journal

Vol-4, Issue-3, 2020 (IJEBAR)

E-ISSN: 2614-1280 P-ISSN 2622-4771

http://jurnal.stie-aas.ac.id/index.php/IJEBAR

This study uses survey techniques by distributing questionnaires, then the information obtained is processed using statistical methods using smart PLS software. The data analysis method used is PLS (Partial Least Square).

The analytical method used in this study is a structural model or path analysis to determine the causal relationship between latent variables that are simultaneously structural.

\section{Discussion}

Research Model Using Partial Least Square

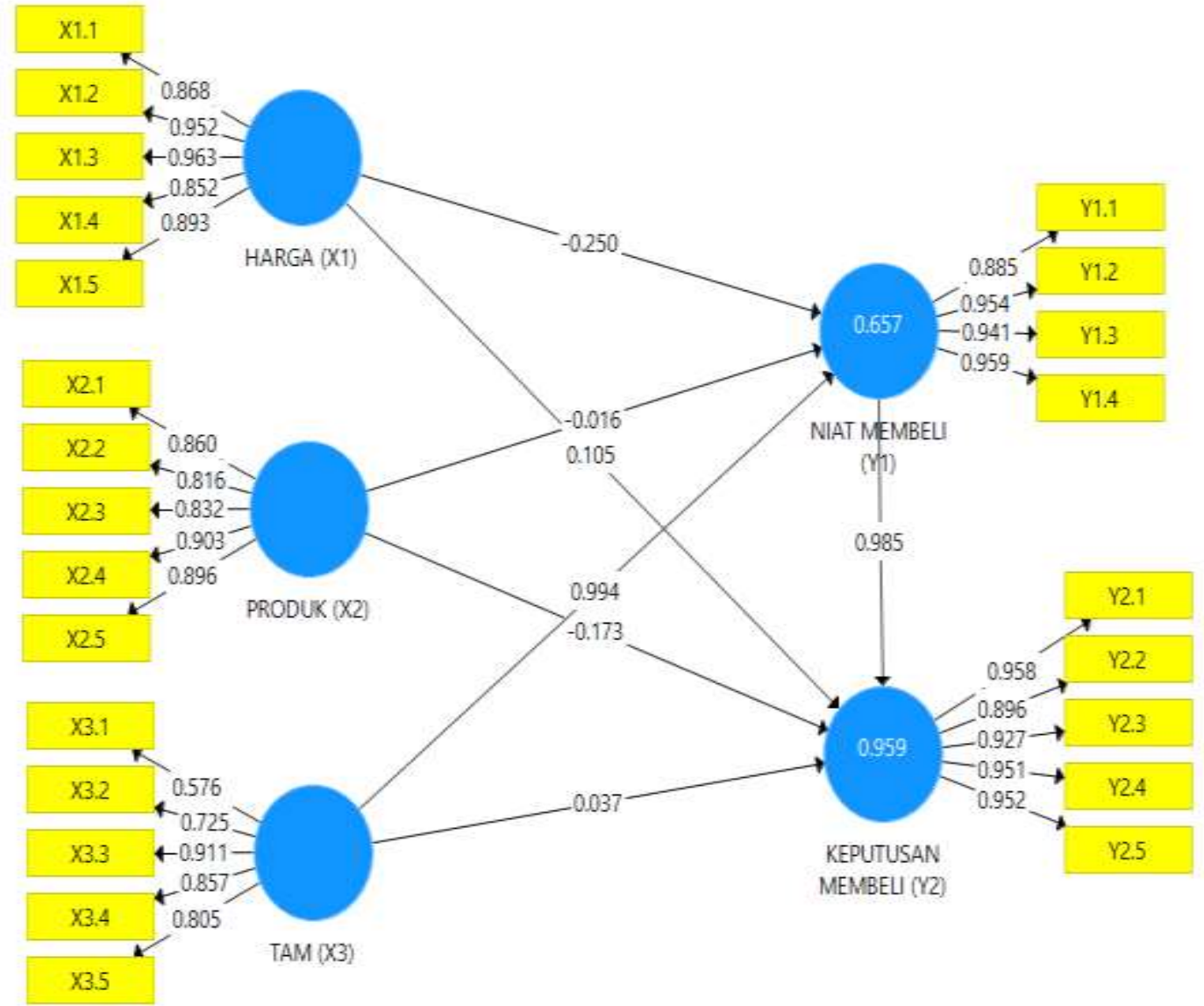

Figure 1:

Structural Research Model

Validity is assessed by looking at convergent validity (the amount of the original sample estimate / loading factor for each construct). A loading factor of 0.70 is highly recommended, however the loading factor of 0.5-0.6 can still be tolerated as long as the model is still under development. The loading factor value of all constructs of the item indicator is above 0.7 so that the research instrument is said to meet convergent validity and the research can proceed to analyze the measurement model or outer model and the structural or inner model.

\section{Goodness of Fit Model Check}

Examination of the model can be seen from the value of R2 (R-square). This means that the model can explain the phenomena or variations in purchasing decisions and purchase intentions can be explained by price, product quality and technology acceptance models, while the structural model in this study is as follows: 
International Journal of Economics, Business and Accounting Research (IJEBAR)

Peer Reviewed - International Journal

Vol-4, Issue-3, 2020 (IJEBAR)

E-ISSN: 2614-1280 P-ISSN 2622-4771

http://jurnal.stie-aas.ac.id/index.php/IJEBAR

Table 2 : R-square

\begin{tabular}{|l|l|}
\hline Variable & $\mathrm{R}^{2}$ \\
\hline Purchase decision & 0.959 \\
\hline Purchase intention & 0.657 \\
\hline
\end{tabular}

Source: Data processing with PLS, 2020.

\section{T-test testing}

Testing the inner model or structural model is done to see the relationship between the constructs of the research model. The basis used in testing hypotheses is the value contained in the output result for inner weight. The results of the analysis and hypothesis testing can be seen in the table:

Table 3 : Result For Inner Weights

\begin{tabular}{|l|l|l|}
\hline Construct & $\begin{array}{l}\text { Original } \\
\text { Sample }\end{array}$ & P Values \\
\hline Price $\rightarrow$ Purchase intention & -0.226 & 0.309 \\
\hline Product quality $\rightarrow$ Purchase intention & -0.018 & 0.945 \\
\hline $\begin{array}{l}\text { Technology Acceptance Model } \rightarrow \text { Purchase } \\
\text { intention }\end{array}$ & 0.962 & 0.00005 \\
\hline Price $\rightarrow$ Purchase decision & 0.156 & 0.331 \\
\hline $\begin{array}{l}\text { Technology Acceptance Model } \rightarrow \text { Purchase } \\
\text { decision }\end{array}$ & -0.015 & 0.926 \\
\hline Product quality $\rightarrow$ Purchase decision & -0.203 & 0.239 \\
\hline Purchase Intention $\rightarrow$ Purchase decision & 0.973 & 0.00009 \\
\hline
\end{tabular}

Smart PLS Output Source, 2020

Based on the Table, it can be seen the influence and significance level of each variable, if $\mathrm{P}$ Value $<0.05$ means that the exogenous variable gives a significant influence on endogenous variables and if $\mathrm{P}$ Value> 0.05 , the exogenous variable gives no significant effect on endogenous variables with an explanation as follows:

1) The price has no significant negative effect on the purchase intention of PT Aplikanusa Lintasarta consumers with a coefficient value of -0.226 and a p-value of 0.309 .

2) Product quality has no significant negative effect on purchase intentions of PT Aplikanusa Lintasarta consumers with a coefficient value of -0.018 and p-value of 0.945 .

3) Technology acceptance model has a significant positive effect on purchase intentions of PT Aplikanusa Lintasarta consumers with a coefficient value of 0.962 and a p-value of 0.00005 .

4) Price does not have a significant positive effect on buying decisions on consumers of PT Aplikanusa Lintasarta, with a coefficient value of 0.156 and a p-value of 0.331 .

5) Technology acceptance model does not have a significant negative effect on the purchase intention decisions of PT Aplikanusa Lintasarta consumers with a coefficient value of -0.015 and p-value of 0.926

6) Product quality is not significant negative effect on buying decisions on consumers PT Aplikanusa Lintasarta with a coefficient value of -0.203 and p-value of 0.239

7) Buying intention has a significant positive effect on buying decisions on PT Aplikanusa Lintasarta consumers with a coefficient value of 0.973 and a p-value of 0.00009

5. Conclusions And Recommendations

Based on the results of research and discussion that has been done, the following conclusions can be drawn:

1) Price variable (X1) has a negative and not significant effect on purchase intention (Y1).

2) The product quality variable (X2) has a negative and not significant effect on purchase intention (Y1). 
International Journal of Economics, Business and Accounting Research (IJEBAR)

Peer Reviewed - International Journal

Vol-4, Issue-3, 2020 (IJEBAR)

E-ISSN: 2614-1280 P-ISSN 2622-4771

http://jurnal.stie-aas.ac.id/index.php/IJEBAR

3) The variable technology acceptance model (X3) has a positive and significant effect on purchase intention (Y1).

4) Price variable (X1) has a positive and not significant effect on buying decisions (Y2)

5) The technology acceptance model variable (X3) has a negative and not significant effect on the buying decision (Y2).

6) The product quality variable (X2) has a negative and not significant effect on buying decisions (Y2).

7) Variable purchase intention (Y1) has a positive and significant effect on buying decisions (Y2).

Based on the conclusions stated above, it is suggested as follows:

1) Lintasarta provides price pricelist sharing to customers who will use virtual private server products such as sending prices via email so that customers can compare Lintasarta prices with other providers and there will be an intention to buy this product.

2) Lintasarta provides sharing of virtual private server products and shows its advantages such as providing brochures or holding discussions with customers so that it raises the intention of buying this product.

3) Lintasarta further increases the sharing of services provided so that the value of the technology acceptance model remains high on the customer side and raises the intention to buy this product.

4) Lintasarta further increases approach to customers, both formal and informal, to educate them on the price provided, compared to other providers, so that customers can immediately decide to buy the product.

5) Lintasarta continues to share related services provided so that the technology acceptance model on the customer's side remains high and the customer immediately decides to buy the product to Lintasarta compared to other providers.

6) Lintasarta must more often provide product sharing such as discussion activities with customers both formal and informal to its customers so that customers are more familiar with the quality provided and immediately decide to buy VPS products.

7) Lintasarta must more often encourage customers who already have the intention by continuing to remind the need to buy a VPS so that customers immediately buy this VPS product.

\section{References}

Ajay and potti, 2017. Effect of Website Quality on Customer Satisfaction and Purchase Intention in Online Travel Ticket Booking Websites: Journal of Management, Vol. 7, No. 5. Pp.168-173

Andi dan Febriliyan, 2017. Analysis of Factors Influencing Purchase Decision In Online Store. Case Study: Game Sales in Online Store: International

Journal of Education and Research, Vol.5 No. 7, pp 277-287

Armstrong, Kotler 2015, Marketing an Introducing Prentice Hall twelfth edition, England : Pearson Education, Inc

Ajzen, I. 1991. The theory of planned behavior. Organizational Behavior and Human Decision Processes, Vol. 50 No.2. pp. 179-211.

Azahari and Fais. 2013. Investigating the Relationship between Trust and Intention to Purchase Online: Business and Management Horizons. $\quad$ Vol.1 No. 1. Pp. 1-7

Baruna, et al. 2017. The Influence of Quality Products, Price, Promotion, and Location to Product Purchase Decision on Nitchi At PT. Jaya Swarasa Agung in Central Jakarta: Saudi Journal of Business and Management Studies. Vol.2, Iss-4B . pp . 433-445

Bing $\mathrm{Xu}^{*}$ and Jianhui Chen. 2017. Consumer Purchase Decision Making Process Based on the Traditional Clothing Shopping Form: Journal Fashion Technology Textile Engineering. Vol. 5 Iss. 3. Pp. 01-12

Choy, et al. 2011. Consumers' Perceived Quality, Perceived Value and Perceived Risk Towards Purchase Decision on Automobile: American Journal of Economics and Business Administration, Vol. 3 No. 1, pp.45-57 
International Journal of Economics, Business and Accounting Research (IJEBAR)

Peer Reviewed - International Journal

Vol-4, Issue-3, 2020 (IJEBAR)

E-ISSN: 2614-1280 P-ISSN 2622-4771

http://jurnal.stie-aas.ac.id/index.php/IJEBAR

Davis, F.F., 1989. Perceived Usefulness, Perceived Ease of Use, and User Acceptance of Information Technology: Management Information System Quarterl. Vol. 13 No. 3, pp. 319-340

Faryabi et al. 2012. The Effect of Price Discounts and Store Image on Consumer's Purchase Intention in Online Shopping Context Case Study: Nokia and HTC: Journal of Business Studies Quarterly.Vol.4, No.1, pp. 197-205

Gusti, et al. 2016. The Role Of Endorser Credibility And Advertising Shampoo Pantene creativity in Altitude, Intention. And Consumer Purchase Decision: International Journal of Business and Management Invention. Vol. 5 Issue 2, pp. 01-13

lason . et al. 2014, Purchase decisions of Greek consumers an empirical study: Procedia Economics and Finance. Vol. 9 .pp 456-465

John and Orville, 2013. Marketing Management A Strategic Decision Making Approach.New York: Mc Grow-Hill Irwin

Kim, E., Hong. T 2010. Segmentating Customers in Online Stores from Factors that Affect the Customer's Intention to Purchase.pp. 383-388

Kim and Song 2010. The Quality of Word of Mouth in the Online Shopping Mall: Joumal of Research in Interactive Marketing, 4(4), 376390

Kotler and Keller, 2009. Manajemen Pemasaran. Jilid 1 Edisi ke 3. Jakarta Erlangga

Kotler and Armstrong 2008, Prinsip prinsip Pemasaran Jilid 1 Edisi 12. Alih Bahasa : Bob Sabran. Jakarta : Erlangga

Kotler and Armstrong. 2011. Marketing an Introduction edition $10^{\text {th }}$ Indonesia: Pearson

Kotler and Amstrong. 2012. Principles of Marketing. New Jersey:Pearson Education Limited

Kotler and Armstrong 2014. Principle Of Marketing, 15th edition. New Jersey:Pearson Prentice Hall.

Kotler and Keller, 2009. Manajemen Pemasaran. Jilid 1 Edisi ke 3.Jakarta: Erlangga

Kotler and Keller. 2016. Marketing Management 16 edition. New Jersey Pearson

Mohd Rizaimy, et al. 2011. The relationship between product quality and purchase intention: The case of Malaysia's national motorcycle/scooter manufacturer: African Journal of Business Management. Vol 5 No. 20,pp. 8163-8176

Sumarwan, Ujang. 2010. Perilaku Konsumen : Teori dab Penerapannyadalam Pemasaran. Ghalia Indonesia : Jakarta

Suwandari, 2008. Pengaruh Promotional Mix pada Peningkatan Volume Penjualan Kosmetika Skiva PT. Cosmolab Prima di Purwokerto. Purwokerto: STMIK Amikom. Jurnal Pro Bisnis, Vol. 1

Raed. 2015. The Impact of Brand Dimension on the Purchasing Decision Making of the Jordanian Consumer for Shopping Goods: International Journal of Business and Social Science. Vol. 6, No. 7.pp. 149-168

Ranna dan Maya. 2016. The Relations Among Service Quality. PerceivedValue, Customer Satisfaction, and Post Purchase Intention In Steam's Online Gaming Service: e-Proceeding of Management. Vol 4, No.1. pp 600-606

Ren-Fang and Ping-Chu. 2016. The Impact of Brand Image and Discounted Price on Purchase Intention in Outlet Mall: Consumer Attitude as Mediator: The Journal of Global Business Management, Vol. 12, No. 2 pp. 119-126

Richard and Hao-hong. 2014. Sales Promotion and Purchasing Intention: Applying the Technology Acceptance Model in Consumer-to Consumer Marketplaces: International Journal of Business Humanities and Technology. Vol 4, No. 3. pp. 01-04

Richard, et al. 2013. The Impact of Product Quality on Perceived Value, Trust and Students Intention to Purchase Electronic Gadgets Mediterranean Journal of Social Sciences MCSER Publishing, Rome Italy, Vol. 4, No. 14, pp 463-470

Rong-Da 2016. Predicting intentions to purchase organic food:the moderating effects of organic food prices British Food Journal, Vol. 118 No. 1. pp. 183-199

Suparyanto. 2015. Manajemen Pemasaran. Bogor: In Media 
International Journal of Economics, Business and Accounting Research (IJEBAR)

Peer Reviewed - International Journal

Vol-4, Issue-3, 2020 (IJEBAR)

E-ISSN: 2614-1280 P-ISSN 2622-4771

http://jurnal.stie-aas.ac.id/index.php/IJEBAR

Surpiko dan Ida. 2015. Pengaruh Technology Acceptance Model Terhadap Pembelian Furniture Dan Handycrat Produk Ukm Melalui Media Online Di Yogyakarta: Jurnal Ilmu Komunikasi, Vol. 13, No. 2, pp 135-144

Thuy and Chi, 2015. Factors Influencing Customer Perceived Quality and Purchase Intention toward Private Labels in the Vietnam Market: The Moderating Effects of Store Image: International Journal of Marketing Studies, Vol. 7, No. 4. pp 51-60

Venkatesh and Davis, F.D., 2000. A theoretical extension of the Technology Acceptance Model: Four Longitudinal Field Studies, Management Science, Vol.46 pp.186-204.

Yi Jin. Et al. 2016. Factors Influencing Online Shopping Behavior: The Mediating Role of Purchase Intention: Procedia Economics and Finance. Vol.35 . pp 401-410 